\title{
New species of unilocular calcareous foraminifera from the Holocene of the southwest Pacific Ocean
}

\author{
FRED E. CLARK \\ Department of Geology, University of Alberta, Edmonton, Alberta, Canada T6G 2 E3.
}

\begin{abstract}
Four new species of unilocular calcareous foraminifera are described from Holocene sediments of the southwest Pacific Ocean. Vasicostella cranimorpha $\mathrm{sp}$. nov. is distinguished by a lenticular tubule that pierces each margin of the peripheral carina. Globofissurella pattersoni sp. nov. is characterized by a large, produced circular apertural area ornamented in part by costae continuing from the chamber surface. Palliolatella peponisema sp. nov. bears a strong resemblance to a pumpkin seed, and has quite variable development of its central keel. Parafissurina thryptica sp. nov. is distinctly teardrop-shaped, with its greatest diameter near the base, and a mildly acute apertural end. J. Micropalaeontol. 14(1): 1-5, April 1995.
\end{abstract}

\section{INTRODUCTION}

Unilocular foraminifera from the southwest Pacific Ocean have been the subject of some significant studies, chief among them being F.W.O. Rymer Jones (1874), Millett (1901a, b, c), and Sidebottom $(1912,1913)$. In the present study, the benthic foraminifera in a suite of 62 Holocene sediment samples were examined. The sites are widely distributed across the tropical southwest Pacific Ocean, and span a range of water depths from $110-8900 \mathrm{~m}$. A total of 141 species of unilocular calcareous foraminifera were identified in the course of the study. Of these, 109 were referable to known species, while most of the remaining 32 species were represented by single or poorly preserved specimens. However, four of these species are represented by several excellent specimens with consistent features, and are described and named herein.

\section{MATERIALS}

All samples examined in this study were from the core collections of Scripps Institution of Oceanography, La Jolla, California. Information concerning the samples yielding the new species described herein is given in Table 1.

\section{TYPE SPECIMENS}

All holotype and paratype specimens denoted by the GSC prefix are deposited in the collections of the Geological Survey of Canada, Ottawa. Paratypes denoted by the RTP prefix are deposited in the collections of the Department of Earth Sciences, Carleton University, Ottawa.

\section{SYSTEMATIC DESCRIPTIONS}

Suprageneric classification follows that of Loeblich \& Tappan (1987).

Suborder Lagenina Delage \& Hérouard, 1896

Superfamily Nodosariacea Ehrenberg, 1838

Family EIlipsolagenidae A. Silvestri, 1923

Subfamily Oolininae Loeblich \& Tappan, 1961

Genus Vasicostella Patterson \& Richardson, 1987
Remarks. This genus, with its longitudinally arranged surface sculpture of costae, nodes, or punctae, is distinguished from Fissurina Reuss, 1850 which has a smooth surface.

\section{Vasicostella cranimorpha sp. nov.}

(Pl. 1, figs 1-5)

1984 Fissurina sp. 4 R.W. Jones: 116, pl. 4, fig. 9.

Derivation of name. From the Greek, kranos, helmet, tmorphe, form, with reference to this ribbed species' resemblance in face view to a helmet, particularly a style of bicycle helmet currently in vogue.

Diagnosis. A species of Vasicostella completely encircled by a broad keel, usually with a single large lenticular tubule in each margin, the chamber faces furnished with coarse longitudinal costae that usually run to the base and aperture.

Types and occurrence. Figured holotype GSC 104618, figured paratype GSC 104619, and unfigured paratypes GSC 104620 and RTP 01596 are all from site LSDH 64G, at a water depth of $4070 \mathrm{~m}$. No other specimens have been recovered. Paratype RTP 01596 is labelled Vasicostella sp. A.

Description. Test unilocular, not much compressed, ovate in outline, 1.4 times as long as broad, base somewhat angled to rounded, apertural end somewhat angled in outline. Aperture terminal, round, in a produced tubular neck, with lip and entosolenian tube; details of tube obscured by frosted surface and sediment filling chamber, but apparently not attached to wall. Periphery completely encircled by wide thin keel that merges with imperforate apertural lip. Keel pierced on each margin by a wide but strongly compressed lenticular tubule whose upper edge is near midpoint of test; rarely just one margin pierced. Chamber furnished on each face with five or more strong costae; some originate well up apertural neck and usually run to base of keel, rather than base of chamber; other less extensive costae occasionally produced by bifurcation 


\begin{tabular}{|c|c|c|c|c|c|}
\hline Sample No. & $\begin{array}{l}\text { Latitude } \\
\text { (South) }\end{array}$ & $\begin{array}{l}\text { Longitude } \\
\text { (East) }\end{array}$ & $\begin{array}{l}\text { Depth } \\
\text { (m) }\end{array}$ & $\begin{array}{l}\text { Interval } \\
(\mathrm{cm})\end{array}$ & Lithology \\
\hline DODO 48D & $07^{\circ} 50.0^{\prime}$ & $153^{\circ} 00.0^{\prime}$ & 4783 & surf. & Chocolate brown ooze. \\
\hline DODO $50 \mathrm{G}$ & $11^{\circ} 30.0^{\prime}$ & $150^{\circ} 30.0^{\prime}$ & 2681 & $2-4$ & Grey-brown ooze. \\
\hline ERDC 19G & $12^{\circ} 12.4^{\prime}$ & $177^{\circ} 11.0^{\prime}$ & 3487 & $0-2$ & Light brown ooze. \\
\hline ERDC $20 \mathrm{G}$ & $15^{\circ} 30.6^{\prime}$ & $172^{\circ} 45.1^{\prime}$ & 3447 & $3-5$ & Light brown ooze. \\
\hline ERDC $115 G$ & $01^{\circ} 38.7^{\prime}$ & $159^{\circ} 11.9^{\prime}$ & 2157 & $0-2$ & Light $\tan$ ooze. \\
\hline ERDC $121 G$ & $00^{\circ} 01.1^{\prime}$ & $158^{\circ} 42.8^{\prime}$ & 2245 & $1-3$ & Light crean-grey ooze. \\
\hline ERDC 132PG & $00^{\circ} 02.6^{\prime}$ & $162^{\circ} 41.0^{\prime}$ & 4441 & $1-2$ & Light cream-tan oozè. \\
\hline LSDH 58G & $14^{\circ} 30.0^{\prime}$ & $148^{\circ} 42.0^{\prime}$ & 2122 & $8-9$ & Grey-tan ooze. \\
\hline LSDH $64 \mathrm{G}$ & $16^{\circ} 03.0^{\prime}$ & $155^{\circ} 00.0^{\prime}$ & 4070 & $5-7$ & Tan-brown ooze. \\
\hline LSDH $65 \mathrm{G}$ & $14^{\circ} 47.0^{\prime}$ & $155^{\circ} 56.0^{\prime}$ & 2982 & $6-8$ & Light brown ooze. \\
\hline LSDH $66 \mathrm{PG}$ & $13^{\circ} 17.0^{\prime}$ & $156^{\circ} 51.0^{\prime}$ & 2031 & $4-6$ & Light grey-brown ooze. \\
\hline LSDH $76 \mathrm{~V}$ & $06^{\circ} 40.0^{\prime}$ & $163^{\circ} 13.0^{\prime}$ & 3565 & $0-10$ & Cream coloured ooze. \\
\hline LSDH $77 \mathrm{G}$ & $05^{\circ} 42.0^{\prime}$ & $165^{\circ} 25.0^{\prime}$ & 2556 & $3-6$ & Light cream ooze. \\
\hline LSDH $78 \mathrm{~V}$ & $04^{\circ} 30.0^{\prime}$ & $167^{\circ} 58.0^{\prime}$ & 3055 & $0-4$ & Bleached cream coloured ooze. \\
\hline LSDH 79P & $03^{\circ} 23.0^{\prime}$ & $170^{\circ} 02.0^{\prime}$ & 3600 & $2-4$ & Light cream ooze. \\
\hline NOVA-A $64 \mathrm{G}$ & $27^{\circ} 37.0^{\prime}$ & $168^{\circ} 59.0^{\prime}$ & 3182 & $3-5$ & Light tan ooze. \\
\hline NOVA-H $30 \mathrm{~V}$ & $12^{\circ} 39.0^{\prime}$ & $173^{\circ} 44.0^{\prime}$ & 3148 & $0-10$ & Light brown ooze. \\
\hline NOVA-HV $11 \mathrm{G}$ & $27^{\circ} 57.0^{\prime}$ & $166^{\circ} 04.0^{\prime}$ & 3549 & $0-3$ & Light brown-tan-cream ooze. \\
\hline PROA $41 G$ & $12^{\circ} 46.0^{\prime}$ & $163^{\circ} 52.0^{\prime}$ & 4110 & $5-7$ & Mottled tan and brown ooze. \\
\hline PROA 52G & $20^{\circ} 20.0^{\prime}$ & $170^{\circ} 46.0^{\prime}$ & 3140 & $2-4$ & Light red-brown ooze. \\
\hline REC $31 \mathrm{G}$ & $11^{\circ} 41.0^{\prime}$ & $155^{\circ} 20.8^{\prime}$ & 3914 & $3-5$ & Light tan ooze. \\
\hline
\end{tabular}

Table 1. Details of location and lithology for samples yielding new species described in text. Intervals given with core top as $0 \mathrm{~cm}$. Suffixes denote sample or core type as follows: $D$, dredge sample; $G$, gravity core; $P$, piston core; $\mathrm{PG}$, gravity core; $\mathrm{V}$, heat probe, sediment catcher.

or insertion. In one instance, face of chamber completely encircled by outermost costa.

Dimensions. Length of figured holotype GSC 104618 $242 \mu \mathrm{m}$, width $173 \mu \mathrm{m}$; length of figured paratype GSC $104619343 \mu \mathrm{m}$, width $243 \mu \mathrm{m}$.

Remarks. The tubuli, usually one per margin, are distinctive, but were not apparent in the specimen figured by R.W. Jones (1984). This may represent an extreme development of the absence of tubuli, which has been noted in the description, or merely reflect the fact that coating of specimens for SEM work hides the tubuli in lateral view (see Pl. 1, figs 1, 5 this paper). The form wherein the outer costa encircles the chamber face is similar to that described as Lagena clathrata by Brady (1884: 485, pl. 60, fig. 4). However, that form lacks a tubular apertural neck, having a crescentic neck or lip instead. The present species is assigned to Vasicostella Patterson \& Richardson, 1987 on the basis of its coarse costae, as opposed to the fine striae or ribs which characterize Lagnea Popescu, 1983. This latter genus often has a tubulated keel, however, and the present species, with its large tubuli, may represent a transition between the two genera.

\section{Subfamily Ellipsolageninae A. Silvestri, 1923 Genus Globofissurella Patterson, 1986}

Remarks. This genus is barely if at all compressed, the peripheral plane being defined by one pair out of several costae that is more completely developed. In contrast, Fissurina Reuss, 1850 lacks costae and is distinctly compressed.

\section{Globofissurella pattersoni sp. nov.}

(P1. 1, figs 6-10)

?1982 Fissurina gratiosa (Buchner); Boltovskoy \& de Kahn: 426, pl. 4, figs. 8,9.

Derivation of name. In honour of R. T. Patterson's extensive work on unilocular foraminifera.

Diagnosis. A species of Globofissurella in which the costae run well up onto the produced apertural area, which is also nearly circular rather than strongly compressed in section.

\section{Explanation of Plate 1}

Figs 1-3. Vasicostella cranimorpha sp. nov., holotype GSC 104618. Fig. 1, face view, $\times 164$; fig. 2, apertural view, showing tubule on each margin, $\times 161$; fig. 3, edge view, showing lenticular tubule, $\times 175$. Figs 4,5. Vasicostella cranimorpha sp. nov., paratype GSC 104619. Fig. 4, oblique apertural view, showing tubule, $\times 112$; fig. 5 , face view, $\times 112$. Figs 6-8. Globofissurella pattersoni, sp. nov., holotype GSC 104621. Fig. 6 , apertural view, $\times 200$; fig. 7, lateral view, $\times 190$; fig. 8 , basal view, showing carina produced by merging diametrically opposed costae, $\times 200$. Figs 9,10. Globofissurella pattersoni, sp. nov., paratype GSC 104622. Fig. 9, lateral view, $\times 229$; fig. 10, apertural view, $\times 235$. Figs 11,12. Palliolatella peponisema sp. nov., holotype GSC 104625. Fig. 11, lateral view, $\times 172$; fig. 12 , apertural view, $\times 230$. Figs 13,14. Palliolatella peponisema sp. nov., paratype GSC 104626. Fig. 13, lateral view, $\times 227$; fig. 14 , apertural view, $\times 450$. Figs 15,16. Palliolatella peponisema sp. nov., paratype GSC 104627, Fig. 15, lateral view, $\times 161$; fig. 16, paratype GSC 104628 , lateral view, $\times 160$. Figs 17,18. Parafissurina thryptica sp. nov., holotype GSC 104630 . Fig. 17, oral view, $\times 240$; fig. 18 , lateral view, $\times 240$. Figs 19,20. Parafissurina thryptica sp. nov., paratype GSC 104631. Fig. 19, lateral view, $\times 315$; fig. 20, oral view, $\times 310$. Figs 21,22. Parafissurina thryptica sp. nov., paratype GSC 104632. Fig. 21, near basal view from oral side, specimen etched to show entosolenian tube attached to aboral side, $\times 350$; fig. 22, enlargement showing attached tube to be entire, $\times 1600$ 


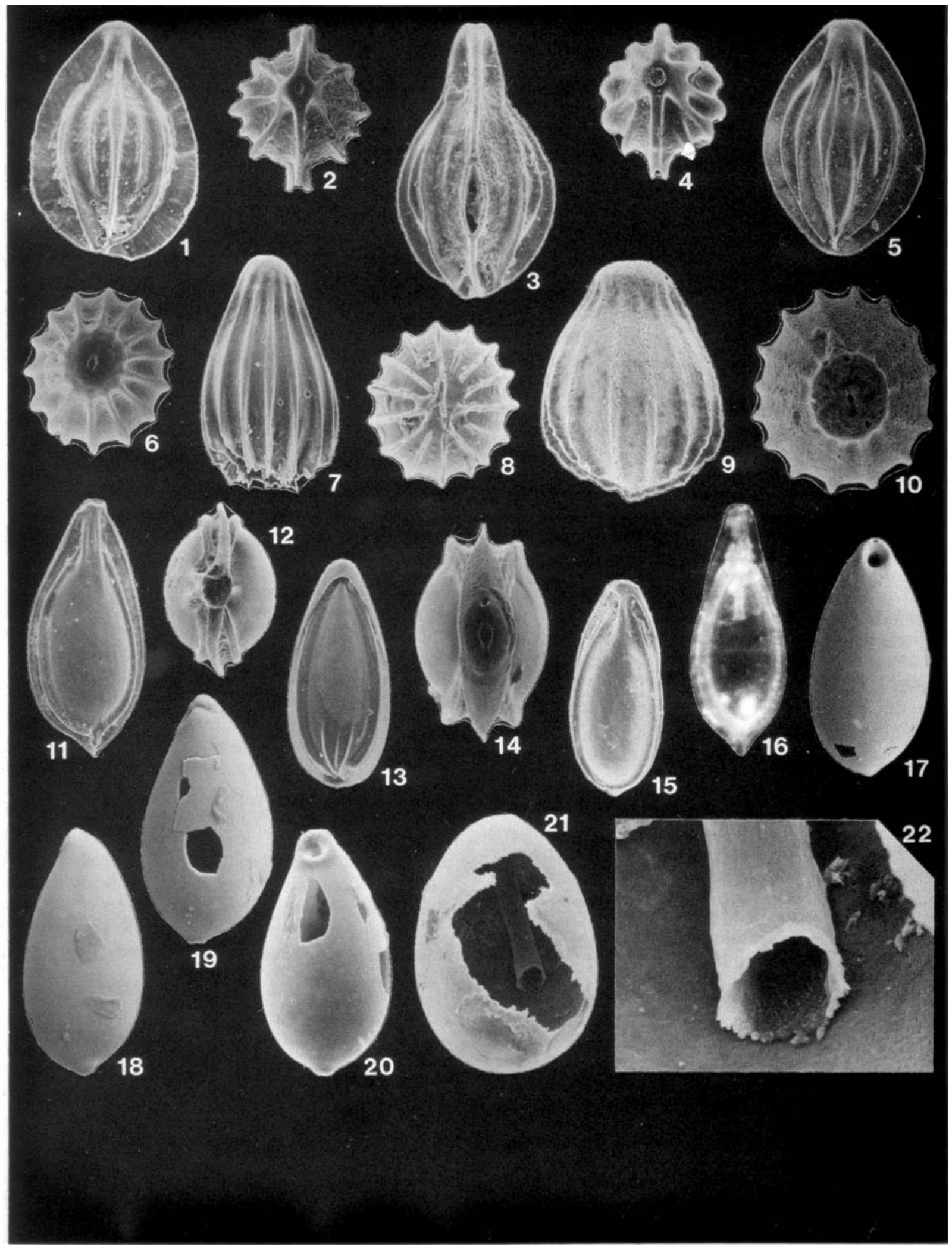

Plate 1 
Types and occurrences. A total of five specimens from five different core samples have been recovered. Figured holotype GSC 104621 is from site LSDH 79P, figured paratype GSC 104622 from site DODO 48D, and unfigured paratypes GSC 104623 from LSDH 76V, GSC 104624 from REC 31G, and RTP 01256 from ERDC 132PG. The water depth range of these sites is $3565-4783 \mathrm{~m}$. Paratype RTP 01256 is labelled Globofissurella sp. A.

Description. Test pyriform in outline, 1.3 to 1.7 times as long as broad, barely compressed, base and apertural end well rounded, chamber somewhat ovate, with constriction before heavy broad convex apertural neck or collar that is hyaline imperforate and almost half as large in outline dimensions as the chamber. Surface with numerous sharp costae, fifteen in the holotype, with one set distinctly continuous across the base, forming a narrow carina. Each face with six to eight costae, not all reaching as far toward base, and none contacting the carina, becoming lower as they pass up chamber onto neck, eventually disappearing over halfway up the neck. Aperture terminal, a small oval opening, with entosolenian tube which appears to be attached to one side, there being no other asymmetrical elements to the test.

Dimensions. Length of figured holotype GSC 104621 $211 \mu \mathrm{m}$, width $124 \mu \mathrm{m}$; length of figured paratype GSC $104622176 \mu \mathrm{m}$, width $135 \mu \mathrm{m}$.

Remarks. This species differs from $G$. bulabrum Patterson, 1986 , in which the costae terminate at the base of the neck, and anastomose at the base, forming a zigzag keel or ridge where they meet. Lagena gratiosa Buchner, 1940 has a longer, constricted, straight neck with a slightly flared lip, all of which is embraced by broad carinal flanges. Boltovskoy \& de Kahn's form clearly does not belong in that species, but it cannot be referred confidently to the present species without a basal view.

Genus Palliolatella Patterson \& Richardson, 1987

Remarks. This genus is distinguished by the peripheral carina which embraces an elongate apertural neck, and is expanded at the apertural end to form a so-called hood.

Palliolatella peponisema sp. nov.

(Pl. 1, figs 11-16)

1982 Fissurina alato-marginata (Jones); Boltovskoy \& de Kahn: 421, pl. 1, figs 1,2.

Derivation of name. From the Latin, pepo, onis, melon, +semen, seed, with reference to its resemblance to a melon or pumpkin seed, especially the raised margin of the latter.

Diagnosis. A species of Palliolatella with the chamber elongate or teardrop-shaped in outline, furnished with three non-tubulated keels of varying extent.

Types and occurrences. This species is represented by twelve specimens from ten core samples. Figured holotype GSC 104625 is from site ERDC 115G, figured paratypes GSC 104626 from LSDH 65G, GSC 104627 from ERDC 132PG, and GSC 104628 from LSDH 66PG, and unfigured paratypes GSC 104629 from ERDC 19G and RTP 01400 from PROA 41G. Other sites with $P$. peponisema were ERDC 20G, LSDH 58G, LSDH 77G, and LSDH 79 P. The resultant water depth range for the species is 2031-4441 m. Paratype RTP 01400 is labelled Palliolatella sp. A.

Description. Test elongate teardrop to subfusiform in outline, 2.2 to 2.5 times as long as broad, greatest breadth below midline, distinctly compressed but chamber faces convex, base apiculate, neck of considerable length, up to one-quarter that of chamber. Periphery ornamented by 3 keels, of which the central one is usually predominant on the upper part, and the outer pair occasionally predominant on the lower part of test. Central keel embraces neck in a rather narrow flange, with the upper surface and lip variably expanded to form an acutely angled hood; often this keel becomes narrow while remaining thin, disappearing by midline of chamber, but may persist with appreciable breadth to base of test, even embracing basal spine. Central keel may be distinctly sigmoid rather than planar in apertural view. Each face encircled by a rather thicker and rounded ridge which thins passing up to base of neck, and may be interrupted at the base to produce a spine or small transverse flange. Lower face of chamber rarely with a few fine costae. Aperture terminal, oval, with free straight entosolenian tube of comparable length to neck.

Dimensions. Length of figured holotype GSC 104625 $246 \mu \mathrm{m}$, width $114 \mu \mathrm{m}$; length of figured paratype GSC $104626176 \mu \mathrm{m}$, width $79 \mu \mathrm{m}$; length of figured paratype GSC $104627228 \mu \mathrm{m}$, width $100 \mu \mathrm{m}$; length of figured paratype GSC $104628263 \mu \mathrm{m}$, width $102 \mu \mathrm{m}$.

Remarks. The teardrop outline, with 3 closely spaced keels of inversely related breadth, is distinctive. Lagena vulgaris Williamson var. alato-marginata F.W. Jones, 1874 has no palliolatelline hood, and has but a single marginal keel, which has broader extensions near the apertural end. It thereby simulates the present species in outline, but the specimens of Boltovskoy \& de Kahn agree well with the present form in being tricarinate. The occasional development of a sigmoid central keel is reminiscent of Tortaguttus Barrick, Beveridge, Patterson \& Schubert, .989, but in that genus, the keel is connected to the adjacent carinae, which are also sigmoid, by a system of transverse fillets.

\section{Subfamily Parafissurininae R.W. Jones, 1984 Genus Parafissurina Parr, 1947 Parafissurina thryptica sp. nov.} (Pl. 1, figs 17-22)

1913 Lagena globosa Montagu sp.; Sidebottom: 164, pl. 15 , figs 1,2 ?, NOT 3 .

Derivation of name. From the Greek, thryptikos, easily broken, with reference to the extremely thin-walled, fragile test.

Diagnosis. A gently elongate, uncompressed species of Parafissurina with its greatest diameter near the base, tapering rapidly to a pointed apertural end. 
Types and occurrences. This species is represented by eleven specimens from ten core samples. Figured holotype GSC 104630 and figured paratype GSC 104632 are from site NOVA-H 30V, figured paratype GSC 104631 from LSDH 79P, and unfigured paratypes GSC 104633 from LSDH 78V, GSC 104634 from PROA 52G, and RTP 01419 from LSDH 58G. Single specimens came from each of sites DODO 50G, ERDC $121 \mathrm{G}$, LSDH $77 \mathrm{G}$, NOVA-A $64 \mathrm{G}$, and NOVA-HV 11G. The resultant water depth range for $P$. thryptica is $2122-3600 \mathrm{~m}$. Paratype RTP 01419 is labelled Parafissurina sp. A.

Description. Test elongate teardrop-shaped, approximately twice as long as broad, circular in section, base well rounded and with caudal structure, tapering thence to very narrow apertural end, which is acute in lateral view. Aperture small, round, completely eccentric and hooded, with entosolenian tube of about half test length attached to aboral wall; tube is entire rather than floored by test wall.

Dimensions. Length of figured holotype GSC 104630 $173 \mu \mathrm{m}$, diameter $84 \mu \mathrm{m}$; length of figured paratype GSC $104631131 \mu \mathrm{m}$, diameter $70 \mu \mathrm{m}$; length of figured paratype GSC $104632170 \mu \mathrm{m}$, diameter $86 \mu \mathrm{m}$.

Remarks. None of Sidebottom's (1913, pl. 15, figs 1-3) forms should have been referred to Vermiculum globosum Montagu, 1803, which has a terminal, round aperture that is neither eccentric nor hooded. The specimen illustrated by Sidebottom as pl. 15, fig. 1 is readily identified with the present species, especially in view of Sidebottom's note that this form is often apiculate. The specimen he illustrated as pl. 15, fig. 2 has a more elongate test with a distinctly tapered base, and may not be referrable to the present species. The form having the globular test with distinct constriction below the aperture that was illustrated by Sidebottom as pl. 15, fig. 3 is clearly not synonymous with Parafissurina thryptica.

Although somewhat similar to Lagena felsinea Fornasini, 1894 and Parafissurina fusuliformis Loeblich \& Tappan, 1953, the present species has its greatest breadth near the base, tapers steadily from there, and has a pointed apertural end. This latter feature distinguishes $P$. thryptica from $P$. himatiostoma Loeblich \& Tappan, 1953, which has a rounded, rather broad apertural end. It is thereby much less strongly tapering than the present species, and somewhat pear-shaped. The present species is also evidently much smaller, and lacks the scattered coarse pores that characterize $P$. himatiostoma.

\section{ACKNOWLEDGMENTS}

This research has been supported by GR-5 monies administered through the Office of Graduate Studies and Research, Carleton University, Ottawa, and by NSERC monies administered through the Central Research Fund, University of Alberta, Edmonton. Thanks are due $\mathrm{K}$. Hooper of Carleton University, who made available the samples from the collection of Scripps Institution of Oceanography, La Jolla, and G. Braybrook of the
Department of Geology, University of Alberta, for his expertise in obtaining the SEM illustrations.

\section{Manuscript received September 1992 \\ Manuscript accepted September 1993}

\section{REFERENCES}

Barrick, R. E., Beveridge, A. E., Patterson, R. T. \& Schubert, J. K. 1989. Tortaguttus, a new unilocular foraminiferal genus. Tulane Studies in Geology and Paleontology, Tulane, 22: 65-67.

Boltovskoy, E. \& de Kahn, G.G. 1982. Foraminiferos bentonicos calcareos uniloculares del Cenozoico superior del Atlantico Sur. Revista de la Asociación Geológica Argentina, 37: 408-448.

Brady, H.B. 1884. Report on the foraminifera dredged by H.M.S. 'Challenger', during the years 1873-1876. In Report on the Scientific Results of the Voyage of the H.M.S. 'Challenger' During the Years 1873-1876, Zoology, 9: 814.

Buchner, P. 1940. Die Lagenen des Golfes von Neapel und der marinen Ablagerungen auf Ischia (Bieträge zur Naturgeschichte der Insel Ischia 1). Nova Acta Leopoldina, n.s., Leipzig, 9: $363-560$.

Fornasini, C. 1894. Lagena felsinea n. sp. Tipografia Gamberini e Parmeggiani, Bologna.

Jones, F. W. O. Rymer. 1874. On some Recent forms of Lagenae from deep-sea soundings in the Java Seas. Transactions of the Linnean Society of London, London, 30(1875): 45-69.

Jones, R. W. 1984. A revised classification of the unilocular Nodosariida and Buliminida (Foraminifera). Revista Española de Micropaleontología, Madrid, 16: 91-160.

Loeblich, A. R. Jr. \& Tappan, H. 1953. Studies of Arctic foraminifera. Smithsonian Miscellaneous Collections, Washington, D.C., 121: 1-150.

Loeblich, A.R. Jr. \& Tappan, H. 1987. Foraminiferal genera and their classification. Van Nostrand Reinhold. New York.

Millett, F.W. 1901a. Report on the Recent foraminifera of the Malay Archipelago collected by Mr. A. Durrand; Part X. Journal of the Royal Microscopical Society, London, 1901: 1-11.

Millett, F.W. 1901b. Report on the Recent foraminifera of the Malay Archipelago collected by Mr. A. Durrand; Part XI. Journal of the Royal Microscopical Society, London, 1901: 485-497.

Millett, F.W. 1901c. Report on the Recent foraminifera of the Malay Archipelago collected by Mr. A. Durrand; Part XII. Journal of the Royal Microscopical Society, London, 1901: 619-628, pl. 14.

Montagu, G. 1803. Testacea Britannica, or natural history of British shells, marine, land, and fresh water, including the most minute. J.S. Hollis, Romsey, England.

Parr, W. 1947. The Lagenid foraminifera and their relationships. Proceedings of the Royal Society of Victoria, n.s., Melbourne, 58: $116-133$.

Patterson, R.T. 1986. Globofissurella and Cerebrina, two new foraminiferal genera in the Family Lagenidae. Journal of Micropalaeontology, 5: 65-69.

Patterson, R.T. \& Richardson, R. 1987. A taxonomic revision of the unilocular foraminifera. Journal of Foraminiferal Research, Washington, D.C., 17: 212-216.

Popescu, G. 1983. Marine Middle Miocene monothalamous foraminifera from Romania. Memorii Institutul de Geologie si Geofizic Bucarest, Bucharest, 31: 261-280.

Reuss, A.E. 1850. Neues Foraminiferen aus den Schichten des Osterreichischen Tertiärbeckens. Denkschriften der Kaiserlichen Akademie der Wissenschaften, MathematischNaturwissenschaftlichen Klasse, Wien, 1: 365-390.

Sidebottom, H. 1912. Lagenae of the south-west Pacific Ocean. Journal of the Queckett Microscopical Club, London, ser. 2, 11(1910-1912): 375-434.

Sidebottom, H. 1913. Lagenae of the south-west Pacific Ocean. Journal of the Queckett Microscopical Club, London, ser. 2 , 12(1913-1915): $161-210$. 